\title{
Detailed study of the juice composition of noni (Morinda citrifolia) fruits from Cambodia
}

\author{
Thavarith CHUNHIENG ${ }^{a}$, Ly HAY ${ }^{b}$, Didier MONTET ${ }^{\text {c* }}$
}

a Institut de Technologie du Cambodge, Département G.C.A., Bd de Pochentong, BP 86, Phnom Penh, Cambodia

b Société Théraprim, 82 avenue Pablo Picasso, 92000 Nanterre, France

c CIRAD-AMIS, UR Tropiqual, TA 40/16, 73 rue J-F Breton, 34398 Montpellier Cedex 5, France didier.montet@cirad.fr

${ }^{*}$ Correspondence and reprints

Received 28 August 2003 Accepted 4 October 2004

Fruits, 2005, vol. 60, p. 13-24 (C) 2005 Cirad/EDP Sciences All rights reserved

DOI: 10.1051/fruits:2005008

RESUMEN ESPAÑoL, p. 24

\section{Detailed study of the juice composition of noni (Morinda citrifolia) fruits from Cambodia.}

Abstract - Introduction. Noni (Morinda citrifolia) has a long history related to medical uses in Southeast Asian countries. Today, noni grows in the majority of the southern Pacific areas, in India, the Caribbean, South America and the West Indies. One of the challenges of recent years was to process Morinda citrifolia fruit juice, to make a more modern drug from a traditional product. In order to obtain better understanding of the medicinal characteristics of the noni fruit cultivated in Cambodia, the biochemical and mineral compositions of the raw juice extracted from $M$. citrifolia fruits were determined. Materials and methods. Whole fresh fruits of $M$. citrifolia which came to France from Cambodia were preserved at $-20{ }^{\circ} \mathrm{C}$ during the duration of the experimentation. Commercial Tahitian noni juice was bought pasteurized to be used as a reference. The extraction was carried out on two batches of Cambodian fruits using a hydraulic press. Contents in oil, fatty acids, proteins, amino-acids, sugars and minerals of juices were analyzed. Results. Composition of noni juice of different origin was determined, compared, and discussed in relation to the biochemical and mineral composition of other vegetable oils. Conclusion. The biochemical composition of the noni juice, which showed a high content of antioxidant molecules, is not sufficient to explain the famous medicinal effects of noni juice. Certain molecules, in particular alkaloids, still have to be studied.

Cambodia / Morinda citrifolia / fruit / proximate composition / oils / proteins / mineral content

\section{Étude détaillée de la composition du jus de noni (Morinda citrifolia) cultivé au Cambodge.}

Résumé - Introduction. Le noni (Morinda citrifolia) a une longue histoire liée à ses utilisations médicales dans les pays du sud-est de l'Asie. Aujourd'hui, la plante croit dans la majorité des régions du Pacifique Sud, en Inde, dans les Caraibes, en Amérique du Sud et aux Antilles. L'un des défis de ces dernières années a été de traiter le jus de fruit de $M$. citrifolia, pour utiliser en pharmacopée moderne ce produit traditionnel. Pour mieux comprendre les caractéristiques médicinales du fruit de noni cultivé au Cambodge, les compositions biochimiques et minérales du jus brut extrait de fruits de $M$. citrifolia ont été déterminées. Matériel et méthodes. Des fruits frais entiers de $M$. citrifolia échantillonnés au Cambodge ont été acheminés en France et conservés à $-20^{\circ} \mathrm{C}$ pendant toute la durée de l'expérimentation. Du jus commercial de noni de Tahiti, pasteurisé, a été acheté pour être utilisé comme référence. Une extraction a été effectuée sur deux séries de fruits cambodgiens à l'aide d'une presse hydraulique. Les taux en huile, acides gras, protéines, acides aminés, sucres et éléments minéraux des jus ont été analysés. Résultats. La composition du jus de nonis des différentes origines a été déterminée, comparée, puis discutée par rapport à la composition biochimique et minérale d'autres huiles végétales. Conclusion. La composition biochimique du jus qui a montré une présence forte en molécules antioxydantes n'est pas suffisante pour expliquer les effets médicinaux réputés du jus de noni. Certaines molécules et en particulier les alcaloïdes restent encore à étudier.

Cambodge / Morinda citrifolia / fruit / composition globale / huile / protéine / teneur en éléments minéraux 


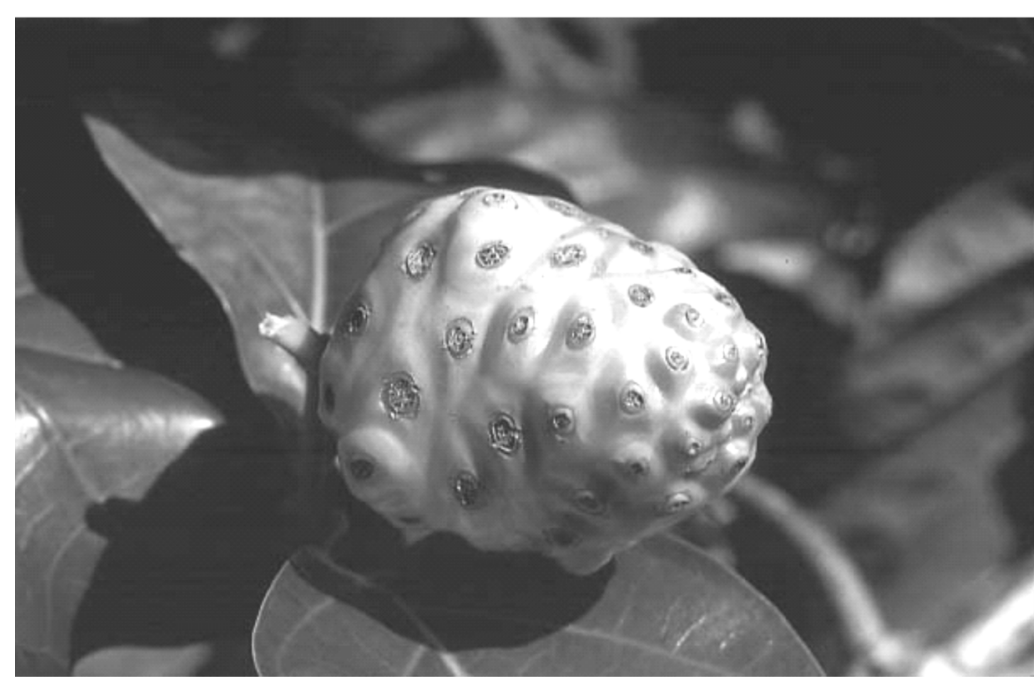

Figure 1. Fruit of Morinda citrifolia.

\section{Introduction}

Noni (Morinda citrifolia) has a long history related to medical uses in the majority of the Southeast Asian countries. It is thought to be the plant predominantly used before the era of modern European medicines. Noni juice is especially known for its medicinal properties: antibacterial, analgesic, anti-congestive, antioxidant, anti-inflammatory, astringent, laxative, sedative and hypo-tensor, which have been cited by many authors [1-4]. Dixon et al. [5] interviewed 185 scientists who identified a total of 346 drugs originating from the noni fruit whose use extends from the treatment of certain specific diseases such as diabetes to more general treatments such as body purging. The therapeutic mechanisms, however, remain unknown [6]

The genus Morinda, Rubiaceae family, includes approximately 80 species, of which less than 20 species are recognized as having an economic value. One species, Morinda citrifolia L., is supreme for its remarkable characteristics, its multiple uses and its distribution [7]. Today, noni grows in the majority of the southern Pacific areas, in India, the Caribbean, South America and the West Indies.

Morinda citrifolia is one of the rare fruit trees which produces fruits 365 days per year. Certain trees can produce up to $2 \mathrm{t}$ of fruits per month. The fruits are thick and have an ovoid form with circular flanges. They measure $20 \mathrm{~cm}$ in length (figure 1); they have a soft and aqueous flesh, a cheese flavor which becomes increasingly marked, and prickling during the process of maturation.

One of the challenges of recent years was to process Morinda citrifolia fruit juice, to make a more modern drug from a traditional product. This plant is indeed known by populations of the tropical world as a drug which can fight against various diseases. It is called "mengkudu" in Malaysia, "nhau" in the southern Pacific Islands, "nonu" in Samao and Tonga, "nono" in Raratonga and Tahiti, and "noni" in the Marquises Islands and Hawaii.

Active molecules present in the noni fruit have been emphasized by certain authors: xeronine by Heinicke [8], terpenes such as asperuloside, aucubine, essential oils, $\beta$-Dglycopyranose pentacetate, asperulocide tetra acetate and ascorbic acid, alizarin carbonate, rubichloric acid and chrysophanol; resins of sterols are also quoted. Others also report the presence of anthraquinones, glycosides, phenolic compounds, resins of $\beta$-sitosterols and ursolic acid.

In order to obtain better knowledge of the characteristics of the noni fruit cultivated in Cambodia, the biochemical and mineral compositions of the raw juice extracted from M. citrifolia fruits were determined and compared with a commercial noni fruit juice originating from Tahiti.

\section{Materials and methods}

\subsection{Fruit of Morinda citrifolia or noni}

The whole fresh fruits of Morinda citrifolia were sent by plane from Cambodia and were preserved at $-20{ }^{\circ} \mathrm{C}$ during the duration of the experiment. Tahitian noni juice (company: Royal Tahiti Noni, made in Tahiti) was bought pasteurized in a pharmacy in Paris to be used as a reference. 


\subsection{Juice extraction}

The extraction was carried out on two batches of fruits using a hydraulic press (Sakaya, Thailand) by increasing to maximum pressure until there was no flow of the juice.

\subsection{Determination of dry matter, mineral composition and moisture content}

Dry matter of the juices was determined after passage in a vacuum dryer (Bioblock) for $24 \mathrm{~h}$ at $70{ }^{\circ} \mathrm{C}$.

Moisture content determination was carried out in triplicate by drying at $(105 \pm 2){ }^{\circ} \mathrm{C}$ for $24 \mathrm{~h}$ [9]. Total ash was obtained by calcination of $5 \mathrm{~g}$ dry matter at $550{ }^{\circ} \mathrm{C}$ and left until a constant mass was obtained [10]. Mineral elements were dosed by Plasma Emission Spectroscopy from Varian Vista ICP [11]. Total nitrogen was analyzed on (50 to 150) mg crushed sample by the catharometry method [12].

\subsection{Amino acid analysis}

Amino acids were determined in duplicate (two hydrolysates per sample, one chromatographic analysis per hydrolysate) by RPHPLC of derived amino acid residues using a Pico Tag C 18 column (3.93 mm internal diameter $\times 15 \mathrm{~cm}$, Waters). Samples $(50 \mathrm{mg}$ ) were hydrolyzed under vacuum in $6 \mathrm{~N} \mathrm{HCl}$ for $24 \mathrm{~h}$ at $110^{\circ} \mathrm{C}$ in sealed tubes. Amino acids were then reacted with phenylisothiocyanate (PITC) with $20 \mathrm{~mL}$ of an ethanol/ triethanolamine/PITC mixture $(7 / 1 / 1)$ to form phenylthiocarbamyl amino acids. Elution was performed with a gradient of acetonitrile in $0.14 \mathrm{M}$ sodium acetate buffer (eluant A: 100\% buffer; eluant B: acetonitrile $60 \%$ in buffer $\mathrm{v} / \mathrm{v}$ ). Tryptophan was not analyzed. Sulfur amino acids were analyzed after performing oxidation, in the form of cysteic methionine sulfone and cysteic acid. Oil was extracted from $10 \mathrm{~g}$ of dry juice for $6 \mathrm{~h}$ by Soxhlet with hexane. The hexane was removed by evaporating and then flushing with nitrogen gas.

\subsection{Oil content determination of the juice}

Three methods of oil extraction were tested: - For Soxhlet extraction with hexane [13], the raw juice was first of all freeze-dried for $24 \mathrm{~h}$, then oil was extracted by Soxhlet with hexane for $6 \mathrm{~h}$.

- For extraction with hexane juice, $20 \mathrm{~g}$ of raw juice was poured into a 1-L separating funnel and was agitated with $100 \mathrm{~mL}$ hexane. The lower aqueous phase was collected then re-extracted with hexane 3 times. The hexanic phases were collected and washed with distilled water 3 times. The hexanic phase was then dried with anhydrous sodium sulfate, and then concentrated with a rotary evaporator. After distillation of hexane and elimination of the last traces under a nitrogen flow, the total lipid content was obtained by weighing.

- For extraction by the method of Folch et al. [14], $20 \mathrm{~g}$ of raw juice was homogenized using a mixer in $20 \mathrm{~mL}$ methanol acidified by $100 \mathrm{~mL}$ acetic acid. Ten milliliters of chloroform were added successively while agitating, then $20 \mathrm{~mL}$ distilled water. The solution was then centrifuged at $6000 \mathrm{~g}$ for $15 \mathrm{~min}$. The chloroformic lower phase was concentrated with a rotary evaporator. After distillation of the chloroform, the total lipids were obtained by weighing.

\subsection{Fatty acid composition and calculation of iodine index}

\subsubsection{Preparation of fatty acids methyl esters (FAME)}

Sodium methylate solution $(3 \mathrm{~mL})$ was added to three drops (roughly $45 \mathrm{mg}$ ) of extracted oil and heated at $60{ }^{\circ} \mathrm{C}$ for $10 \mathrm{~min}$ [15]. After 10 min of boiling, $3 \mathrm{~mL}$ of methanol chloride was added. The mixture was heated again for $10 \mathrm{~min}$ and cooled to room temperature and subsequently $10 \mathrm{~mL}$ of distilled water and $15 \mathrm{~mL}$ of hexane were added in succession. The mixture was shaken vigorously and left to stand to allow the layers to separate. The upper hexane layer containing FAME was transferred to a small tube and 
stored at $-20{ }^{\circ} \mathrm{C}$ for later analysis by gas-liquid chromatography (GLC).

\subsubsection{FAME analysis}

The FAME analysis was performed by GLC (Ceinstruments, Model GC 8000 Top) equipped with a flame-ionization detector. A Supelcowax 10 column $(0.32 \mathrm{~mm}$ internal diameter $\times 30 \mathrm{~m}$ long, $0.25 \mu \mathrm{m}$ film thickness) with helium carrier gas at a linear flow velocity of $2 \mathrm{~mL} \cdot \mathrm{min}^{-1}$ was used. A temperature program of $100{ }^{\circ} \mathrm{C}$ for $5 \mathrm{~min}$, rising to $230{ }^{\circ} \mathrm{C}$ at a rate of $10^{\circ} \mathrm{C} \cdot \mathrm{min}^{-1}$ was used. The FAME, dissolved in hexane, was injected $(1 \mu \mathrm{L})$ in a split mode. The injector and detector temperatures were $250{ }^{\circ} \mathrm{C}$ and $260{ }^{\circ} \mathrm{C}$, respectively. Peak areas were recorded using a Merck D-200 integrator. Fatty acids were identified by comparison of retention times of palm oil fatty acids and by comparison with the literature values.

The iodine index was calculated from the unsaturated fatty acid content of the oil determined by CPG.

\subsection{Total sugar content and determination of Brix degree}

\subsubsection{Extraction of sugars under reflux of ethanol $80 \%[16]$}

The samples were defatted beforehand with hexane, then $10 \mathrm{~g}$ of them were crushed and agitated with $100 \mathrm{~mL}$ ethanol 80\% before being kept under reflux of ethanol for $1 \mathrm{~h}$. The insoluble residue was reintroduced into $100 \mathrm{~mL}$ ethanol 80\% and the extraction was

\begin{tabular}{|c|c|c|c|}
\hline \multirow{2}{*}{$\begin{array}{l}\text { Time } \\
\text { (min) }\end{array}$} & \multirow[t]{2}{*}{ Flow } & $\mathrm{NaOH} 0.1 \mathrm{M}$ & Sodium acetate $0.2 \mathrm{M}$ \\
\hline & & \multicolumn{2}{|r|}{ (\%) } \\
\hline 0 & 1.00 & 50.0 & 0.0 \\
\hline 24 & 1.00 & 0.0 & 100.0 \\
\hline 30 & 1.00 & 100.0 & 0.0 \\
\hline 33 & 1.00 & 50.0 & 0.0 \\
\hline 36 & end & - & - \\
\hline
\end{tabular}

carried out a second time for $1 \mathrm{~h}$. The insoluble residue was rinsed with ethanol $80 \%$. The ethanol was eliminated at $45^{\circ} \mathrm{C}$ with a rotary evaporator until (15 to 20) $\mathrm{mL}$ extract was obtained, which was adjusted to $50 \mathrm{~mL}$ with pure water before being filtered to $0.2 \mathrm{~mm}$ for chromatographic analysis.

\subsubsection{Dosage of mono- and disaccharides by ionic chromatography [17]}

The solution was diluted to obtain a content for each sugar ranging between ( 5 and 30) $\mathrm{mg} \cdot \mathrm{L}^{-1}$. A quantity of $0.8 \mathrm{~mL}$ of filtered or centrifuged solution was poured into a tube adapted to the automatic sampling machine. Separation was carried out on an ionic chromatograph Dionex DX600 equipped with a column filled with balls of polystyrene-divinyl-benzene from ( 5 to 10$) \mu \mathrm{m}$ with a guard column of anion exchanging Dionex Carbo pac PA1 $(250 \mathrm{~mm} \times 4 \mathrm{~mm})$ and with an amperometric detector (PAD) (table I).

The concentrations were calculated according to the external standard method using a stock solution of orange juice (Joker).

The measurement of Brix degree was carried out using a hand refractometer, graduated in \% (Atago, Brix 0-32\%, Japan).

\subsection{Analysis of raw cellulose [18]}

Raw cellulose corresponds to the residue resistant to the successive acid and alkaline treatments after deduction of the ash content. The residue obtained does not correspond to pure cellulose alone: it is composed of ( 50 to 80 )\% cellulose, (10 to 50 )\% lignin and approximately 20\% hemicellulose.

Samples were defatted beforehand with hexane, then $700 \mathrm{mg}$ of them were finely crushed (about $0.5 \mathrm{~mm}$ ) in a porous sachet (Fibersac 24 Ankom, Humeau) sealed with a thermo-solder. The sachets were introduced into the Fibersac apparatus filled with $2 \mathrm{~L}$ of preheated pure water (conductivity $\left.<5 \mu \mathrm{S} \cdot \mathrm{cm}^{-1}\right)$.

For the acid attack $\left(\mathrm{H}_{2} \mathrm{SO}_{4}\right), 2 \mathrm{~L}$ of $\mathrm{H}_{2} \mathrm{SO}_{4}$ $0.2 \mathrm{~N}$ were introduced into the apparatus. Two milliliters of Termamyl LS (thermostable amylase, Novo Nordisk) and three drops 
of cyclohexanone (antifoaming) were added. The system was closed hermetically. Agitation and heating were maintained for $40 \mathrm{~min}$ at $100{ }^{\circ} \mathrm{C}$ and then stopped. Samples were rinsed two times with boiling, distilled water for $5 \mathrm{~min}$ and then the water was drained.

For the alkaline treatment $(\mathrm{KOH}), 2 \mathrm{~L}$ of $\mathrm{KOH} 0.23 \mathrm{~N}$ were introduced into the apparatus. Two milliliters of Termamyl LS (Novo Nordisk) and three drops of cyclohexane were added. The system was closed hermetically. Agitation and heating were maintained for $40 \mathrm{~min}$ at $100{ }^{\circ} \mathrm{C}$ and then stopped. The sample was rinsed two times with boiling distilled water for $5 \mathrm{~min}$ and then the water was drained. The sachets were rinsed by steeping them in $200 \mathrm{~mL}$ acetone for (2 to 3) min, dried on an absorbing support then deposited on a stainless dish in a drying oven at $(104 \pm 3){ }^{\circ} \mathrm{C}$ for a night and weighed after they returned to ambient temperature.

For mineralization, sachets were deposited in pre-weighed capsules and then placed in a cold muffle furnace. The temperature was increased to $200{ }^{\circ} \mathrm{C}$ in $15 \mathrm{~min}$ and the sample calcinated for $30 \mathrm{~min}$; the temperature was then increased to $515^{\circ} \mathrm{C}$ in $20 \mathrm{~min}$ and maintained for $1 \mathrm{~h}$. The capsules were cooled in a desiccator until room temperature was reached, and weighed. The content of raw cellulose was expressed in $\mathrm{g} \cdot 100 \mathrm{~g}^{-1}$ of raw sample.

\subsection{Chlorophyll quantification}

Chlorophyll content was given according to the spectrophotometric method of Arnon [19]. A glass cuvette of $1 \mathrm{~cm}$ was filled with centrifuged juice. The optical density of the juices was read at $645 \mathrm{~nm}$ and $663 \mathrm{~nm}$ with a Milton Roy spectrophotometer (Spectronic 1201). The results were obtained by the following equation: chlorophyll $\left(\mathrm{mg} \cdot \mathrm{mL}^{-1}\right)=$ $\left[20.2\left(\right.\right.$ DO $\left._{645} \mathrm{~nm}\right)+8.02\left(\right.$ DO $\left.\left._{663} \mathrm{~nm}\right)\right]$.

\subsection{Mineral and organic anion determination [20]}

Standard mineral anions $\left(1 \mathrm{~g} \cdot \mathrm{L}^{-1}\right)$ came from Spin (Limours, France), Fischer (Elancourt, France), or Spex-ion (Longjumeau, France) and organic anions $\left(1 \mathrm{~g} \cdot \mathrm{L}^{-1}\right)$ from Analys
Table II.

Elution profile for assessing mineral and organic anions in fruit juice.

$\begin{array}{lccc}\begin{array}{l}\text { Time } \\ (\min )\end{array} & \mathrm{NaOH} 0.002 \mathrm{M} & \mathrm{NaOH} 0.1 \mathrm{M} & \mathrm{H}_{2} \mathrm{O} \\ & & (\%) & \\ 0 & 40 & 0 & 60 \\ 0.1-0.5 & 40 & 0 & 60 \\ 2 & 40 & 0 & 60 \\ 5 & 56 & 14 & 40 \\ 10 & 90 & 10 & 0 \\ 12 & 85 & 15 & 0 \\ 14 & 72 & 28 & 0 \\ 15 & 72 & 28 & 0 \\ 17 & 60 & 40 & 0 \\ 18 & 18 & 20 & 0\end{array}$

(Manosque, France). A standard solution was prepared with orange juice (Joker) diluted 50 times. The last dilution was carried out with a solution of ethanol $20 \%$. Samples were analyzed on a Dionex chromatograph. A $0.8-\mathrm{mL}$ volume of solution was poured into a tube adapted to the automatic sample machine. Eluants were ultrapure water, decarbonated by helium, soda $50 \%$ (Baker) and $\mathrm{H}_{2} \mathrm{SO}_{4} 96 \%$ for analysis (Carlo Erba) (table II). The column regeneration was done by $\mathrm{H}_{2} \mathrm{SO}_{4} 2 \mathrm{~N}$.

\section{Results and discussions}

\subsection{Dry matter content and Brix degree of noni fruit juices}

The raw noni juice from Cambodia had $8{ }^{\circ}$ Brix and its dry matter was $(9.75 \pm 0.4) \%$ (table III). These values were definitely higher than those obtained for the commercial noni juice from Tahiti which only had $4.8^{\circ}$ Brix and a total dry matter of $(5.1 \pm$ $0.4) \%$.

\subsection{Sugar composition of noni fruit juices}

The two batches of Cambodian raw juices contained the same quantity of glucose 
Table III.

Content of dry matter and Brix degree of raw juice of Morinda citrifolia from Cambodia compared with a commercial noni juice from Tahiti.

\begin{tabular}{lcc}
$\begin{array}{l}\text { Origin of } \\
\text { noni juice }\end{array}$ & ${ }^{\circ}$ Brix & $\begin{array}{c}\text { Dry matter } \\
\left(\mathrm{g} \cdot 100 \mathrm{~g}^{-1} \text { juice }\right)\end{array}$ \\
\hline Cambodia & 8.0 & $9.75 \pm 0.4$ \\
Tahiti & 4.8 & $5.1 \pm 0.4$
\end{tabular}

\section{Table IV.}

Sugar composition of the juice ( $\mathrm{g} \cdot \mathrm{L}^{-1}$ juice) of Morindia citrifolia from Cambodia compared with noni juice from Tahiti.

\begin{tabular}{lrrccc}
$\begin{array}{l}\text { Origin of } \\
\text { noni juice }\end{array}$ & Glucose & Fructose & Sucrose & Cellulose & Total sugars \\
\hline Cambodia & $11.9 \pm 0.2$ & $8.2 \pm 0.2$ & $<0.1$ & $33.8 \pm 0.3$ & $20.1 \pm 0.2$ \\
Tahiti & $8.1 \pm 0.2$ & $10.3 \pm 0.2$ & $0.4 \pm 0.2$ & Not determined & $18.8 \pm 0.2$ \\
\hline
\end{tabular}

(11.9 $\left.\mathrm{g} \cdot \mathrm{L}^{-1}\right)$ and fructose $\left(8.2 \mathrm{~g} \cdot \mathrm{L}^{-1}\right)($ table IV) The commercial Tahitian juice contained an equivalent quantity of glucose $\left(8.1 \mathrm{~g} \cdot \mathrm{L}^{-1}\right)$ and fructose $\left(10.3 \mathrm{~g} \cdot \mathrm{L}^{-1}\right)$. What strongly differentiated the juices from both origins was the content of sucrose, which was very low in the Cambodian juices $\left(<0.1 \mathrm{~g} \cdot \mathrm{L}^{-1}\right)$, whereas $0.4 \mathrm{~g} \cdot \mathrm{L}^{-1}$ was found in the Tahitian juice. The total sugar content (glucose + fructose + sucrose) of Tahitian juice $\left(18.8 \mathrm{~g} \cdot \mathrm{L}^{-1}\right)$ was equivalent to that of the two batches of Cambodian juices $\left(20.1 \mathrm{~g} \cdot \mathrm{L}^{-1}\right)$. This content is lower, for example, than that found in a commercial grapefruit $\left(90 \mathrm{~g} \cdot \mathrm{L}^{-1}\right)$, orange or tangerine juice $\left(100 \mathrm{~g} \cdot \mathrm{L}^{-1}\right)$ [21]. The content of fibers was high for the Cambodian juice $\left(33.8 \mathrm{~g} \cdot \mathrm{L}^{-1}\right)$.

\subsection{Chlorophyll content of noni fruit juices}

The green color of $M$. citrifolia juice was due to the presence of chlorophyll. Densitometric measurement showed that the noni juice contained $0.29 \mathrm{mg}$ chlorophyll $\cdot \mathrm{g}^{-1}$ juice, which is much more than the content of olive oil from various species of Picudo $\left(0.002 \mathrm{mg} \cdot \mathrm{g}^{-1}\right)$ and Picual $\left(0.001 \mathrm{mg} \cdot \mathrm{g}^{-1}\right)$ reported by Minguez-Mosquera et al. [22].

\subsection{Composition of mineral anions and organic acids of noni fruit juices}

The total content of anions of the Cambodian noni juice was $7.9 \mathrm{~g} \cdot \mathrm{L}^{-1}$. It was a little more than that of the commercial juice from Tahiti $\left(5.5 \mathrm{~g} \cdot \mathrm{L}^{-1}\right)$ and it is close to that found in pineapple juice $\left[(4.5\right.$ to 18.7$\left.) \mathrm{g} \cdot \mathrm{L}^{-1}\right]$ (table V). Both the noni juices of Cambodian and Tahitian origin contained little citric acid $\left(0.03 \mathrm{~g} \cdot \mathrm{L}^{-1}\right)$, a hundred times less than in pineapple juice $\left(3.0-13.5 \mathrm{~g} \cdot \mathrm{L}^{-1}\right)$ [21]. The malic acid content of the pineapple juice $\left(1.5-5.2 \mathrm{~g} \cdot \mathrm{L}^{-1}\right)$ is close to that of noni juice $\left(4.6 \mathrm{~g} \cdot \mathrm{L}^{-1}\right)$. The Cambodian juice contained $0.75 \mathrm{~g} \cdot \mathrm{L}^{-1}$ of oxalic acid $(0.075 \%)$ which is lower than spinach $(0.3-1.3 \%)$, tea (0.3-2\%) or cocoa $(0.5-0.9 \%)$. This content will not cause any health problem related to the chelation of salts.

\subsection{Mineral composition of noni fruit juices}

Noni juice contains all the minerals necessary for the human metabolism. Selenium content in the studied juices was between (0.9 and 1.4) $\mu \mathrm{g} \cdot \mathrm{g}^{-1}$ dry matter (table VI). It was higher than that of other foodstuffs such as soya (0.02 to 0.7$) \mu \mathrm{g} \cdot \mathrm{g}^{-1}$ dry matter [23] or potato $0.006 \mu \mathrm{g} \cdot \mathrm{g}^{-1}$ dry matter [21]. Selenium, which is essential to the activity of certain enzymes such as erythrocyte glutathione peroxidase, could protect the body from the harmful effects of free radicals and the phenomena of ageing related to ultraviolet rays. Men need ( 55 to 70 ) $\mu \mathrm{g}$ of selenium per day.

The sulphur content of noni juice (0.30 $\mathrm{g} \cdot 100 \mathrm{~g}^{-1}$ dry matter) was higher than that of Tahitian juice $\left(0.18 \mathrm{~g} \cdot 100 \mathrm{~g}^{-1}\right.$ dry matter). Particular attention must be given to the sulphur content, which could be responsible for odors [24].

Plants and fruits are generally poor in sodium, apart from some vegetable species [25]. The sodium content of Cambodian juice (0.22 $\mathrm{g} \cdot 100 \mathrm{~g}^{-1}$ dry matter) was close to the 
Table V.

Mineral and organic anion composition of juice $\left(\mathrm{g} \cdot \mathrm{L}^{-1}\right.$ juice) from Morinda citrifolia from Cambodia compared with that of Tahitian noni and pineapple juices [21].

$\begin{array}{lcccccccc}\text { Origin of juice } & \text { Acetate } & \text { Chloride } & \text { Citrate } & \text { Malate } & \text { Oxalate } & \text { Phosphate } & \text { Sulfate } & \text { Total } \\ \text { Cambodia } & 0.40 & 1.14 & 0.03 & 4.64 & 0.75 & 0.50 & 0.45 & 7.9 \\ \text { Tahiti } & 0.25 & 0.89 & 0.02 & 3.84 & 0.14 & 0.19 & 0.15 & 5.5 \\ \text { Pineapple } & - & - & 3.0-13.5 & 1.5-5.2 & 0.05 & - & - & 4.5-18.7\end{array}$

Table VI.

Mineral composition of noni juices from Cambodia and Tahiti.

\begin{tabular}{|c|c|c|c|c|c|c|c|c|c|}
\hline \multirow{2}{*}{ Origin of noni juice } & $\mathrm{N}$ & $P$ & $\mathrm{~K}$ & $\mathrm{Ca}$ & $\mathrm{Mg}$ & S & $\mathrm{Na}$ & \multirow{2}{*}{$\begin{array}{c}\mathrm{Se} \\
\left(\mu \mathrm{g} \cdot \mathrm{g}^{-1} \text { dry matter }\right)\end{array}$} & \multirow{2}{*}{$\begin{array}{c}\text { Dry matter } \\
\left(\mathrm{g} \cdot 100 \mathrm{~g}^{-1} \text { juice }\right)\end{array}$} \\
\hline & \multicolumn{7}{|c|}{ (g. $100 \mathrm{~g}^{-1}$ dry matter) } & & \\
\hline Cambodia & 3.64 & 0.25 & 4.01 & 0.29 & 0.14 & 0.30 & 0.22 & 0.9 & 9.75 \\
\hline Tahiti & 0.77 & 0.22 & 4.68 & 0.17 & 0.39 & 0.18 & 0.28 & 1.4 & 5.10 \\
\hline
\end{tabular}

content of Tahitian juice $\left(0.28 \mathrm{~g} \cdot 100 \mathrm{~g}^{-1}\right.$ dry matter). Sodium, with potassium, controls the water balance of the body.

The magnesium content of Tahitian noni juice $\left(0.39 \mathrm{~g} \cdot 100 \mathrm{~g}^{-1}\right.$ dry matter) was higher than that of the Cambodian juice $\left(0.14 \mathrm{~g} \cdot 100 \mathrm{~g}^{-1}\right.$ dry matter). Magnesium is present in practically all tissues. It plays a role in the transport of energy. Human magnesium consumption is often lower than that recommended [(330 to 420) $\mathrm{mg}$ per day]. In extreme magnesium deficiency, cramps, tetany crises, tiredness and insomnia can be observed. Magnesium also has a role in the prevention of cardiovascular diseases.

The calcium content of Cambodian juice $\left(0.29 \mathrm{~g} \cdot 100 \mathrm{~g}^{-1}\right.$ dry matter) is similar to that of soybean $\left(0.25 \mathrm{~g} \cdot 100 \mathrm{~g}^{-1}\right.$ dry matter) [21], but lower than the calcium content of cow's milk (1.3 g.100 g $\mathrm{g}^{-1}$ dry matter) [25]. These low contents are partly explained by the low solubility of calcium in juices. Consumption of food rich in calcium (e.g., dairy products) is strongly recommended for people at risk: old people, diabetics, etc. Calcium is especially a constituent of the skeleton. Its content in blood plasma is narrowly controlled at $100 \mathrm{mg} \cdot \mathrm{L}^{-1}$ and it plays a favorable role in the blood pressure. Plants contain a low amount of calcium. Biological activity of calcium and phosphorus are dependent and their ratio $[\mathrm{Ca} / \mathrm{P}]$ must be close to 1.7 [25].

The potassium content of Tahitian juice (4.68 $\mathrm{g} \cdot 100 \mathrm{~g}^{-1}$ dry matter) was equivalent to that of Cambodian juice $\left(4.01 \mathrm{~g} \cdot 100 \mathrm{~g}^{-1}\right.$ dry matter). This content is higher than that found in cow's milk ( $1.6 \mathrm{~g} \cdot 100 \mathrm{~g}^{-1}$ dry matter) [25]. The destiny of $\mathrm{K}$, in the body, is closely related to that of $\mathrm{Na}$. It is necessary for the activity of a multitude of enzymes, for the correct neuromuscular and cardiac processes, stomach acid secretion and aldosterone regulation. The human requirement for $\mathrm{K}$ is about 390 to $585 \mathrm{mg}$ per day. A normal diet provides from ( 2 to 6 ) g of $\mathrm{K}$ per day. Fruits and vegetables abound in K. The potassium contents of pineapple flesh and bananas are (0.3 and 1.2-3.0) $\mathrm{g} \cdot 100 \mathrm{~g}^{-1}$ dry matter, respectively [21]. The potassium contents of cauliflowers, soya and beans from Lima are $\left(0.3,1.1\right.$ and 1.6) $\mathrm{g} \cdot 100 \mathrm{~g}^{-1}$ dry matter, respectively [21].

The phosphorus contents of Cambodian juice and Tahitian juice are low [(0.25 and $0.22) \mathrm{g} \cdot 100 \mathrm{~g}^{-1}$ dry matter, respectively] compared with those of soybeans $\left(0.58 \mathrm{~g} \cdot 100 \mathrm{~g}^{-1}\right.$ 
Table VII.

Calculation of the conversion factor for nitrogen/protein for noni juice proteins.

$\begin{array}{lcccc}\text { Amino acids studied } & \begin{array}{c}\text { Amino acids } \\ (\%)\end{array} & \begin{array}{c}\text { Molecular weight } \\ (\mathrm{g})\end{array} & \begin{array}{c}\text { Nitrogen per molecular weight } \\ \left(\mathrm{g} \cdot \mathrm{g}^{-1} \text { amino acid) }\right.\end{array} & \begin{array}{c}\text { Nitrogen } \\ \left(\mathrm{g} \cdot 100 \mathrm{~g}^{-1} \text { dry juice }\right)\end{array} \\ \text { Alanine } & 5.56 & 89.09 & 0.157 & 0.874 \\ \text { Arginine } & 6.88 & 174.20 & 0.321 & 2.213 \\ \text { Aspartic acid } & 10.50 & 133.10 & 0.105 & 1.104 \\ \text { Glutamic acid } & 9.00 & 147.10 & 0.095 & 0.856 \\ \text { Glycine } & 4.95 & 75.07 & 0.186 & 0.921 \\ \text { Histidine } & 6.00 & 155.16 & 0.270 & 1.624 \\ \text { Isoleucine } & 10.86 & 131.18 & 0.107 & 1.158 \\ \text { Leucine } & 6.53 & 131.18 & 0.107 & 0.697 \\ \text { Lysine } & 5.3 & 146.19 & 0.191 & 1.014 \\ \text { Phenylalanine } & 4.85 & 165.19 & 0.085 & 0.411 \\ \text { Proline } & 5.56 & 115.13 & 0.122 & 0.676 \\ \text { Serine } & 5.2 & 105.09 & 0.133 & 0.693 \\ \text { Threonine } & 6.09 & 119.12 & 0.117 & 0.716 \\ \text { Tyrosine } & 6.97 & 181.19 & 0.077 & 0.538 \\ \text { Valine } & 5.74 & 117.15 & 0.119 & 0.685 \\ \text { Total } & 100.00 & - & - & 14.18\end{array}$

dry matter) [21] or cow's milk (1 g.100 $\mathrm{g}^{-1}$ dry matter) [25]. In the human body, $80 \%$ of the phosphorus is present in the form of a calcium salt in the skeleton and the teeth; it also intervenes in the use and storage of energy and in enzymatic activities. Human needs are $800 \mathrm{mg}$ of phosphorus per day.

\subsection{Amino acids and protein content of noni fruit juices}

The amino acid analysis of Cambodian juice proteins (table VII) made it possible to cal-

\section{Table VIII.}

Nitrogen and protein content ( $\mathrm{g} \cdot 100 \mathrm{~g}^{-1}$ dry matter) of noni juices.

\begin{tabular}{lccc} 
Origin of juices & $\begin{array}{c}\text { Total nitrogen } \\
\text { content }\end{array}$ & $\begin{array}{c}\text { Protein content } \\
(\mathrm{N} \times \text { factor 6.25) }\end{array}$ & $\begin{array}{c}\text { Recomputed protein } \\
(\mathrm{N} \times \text { factor 7.05) }\end{array}$ \\
\hline Cambodian noni & 3.64 & 22.7 & 25.7 \\
Cakes & 3.24 & 20.2 & 22.8 \\
Tahitian juice & 0.77 & 4.8 & 5.4
\end{tabular}

culate the exact factor of conversion for nitrogen per protein and thus to calculate the exact content of protein in the juices [26]. Sulphur amino acid analysis (cysteine and methionine) was not carried out because it would have been necessary to carry out an oxidation before acid hydrolysis. In general, with only acid hydrolysis, methionine and cysteine peaks are nevertheless found. In our case, these peaks were very weak and we concluded that there is a very low amount of sulphur amino acids in the juices.

The protein content (table VIII) was obtained by multiplying the total nitrogen content by the international factor of conversion $6.25[21,27]$ and the content of real protein was calculated by multiplying the nitrogen content by the new factor of 7.05 . By taking into account this new factor, the Cambodian juice contained $25.7 \mathrm{~g}$ protein $100 \mathrm{~g}^{-1}$ dry matter. Tahitian juice contained only $5.4 \mathrm{~g}$ protein $100 \mathrm{~g}^{-1}$ dry matter. On the other hand, the protein content of the residual cake obtained after pressing the juice was equivalent to that of raw juice with $22.8 \mathrm{~g}$ protein $\cdot 100 \mathrm{~g}^{-1}$ dry matter. 
Table IX.

Percentage fatty acids composition (oil \%) of the oil of Morinda citrifolia juice compared with that obtained by Farine et al. [28] and that of corn oil [32] and olive oil [31].

\begin{tabular}{|c|c|c|c|c|c|c|c|c|c|c|c|c|c|c|c|c|}
\hline Oil type & $\mathrm{C} 4: 0$ & C6:0 & C8:0 & C10:0 & $\mathrm{C} 12: 0$ & C14:0 & C16:0 & C16:1 & C18:0 & $\begin{array}{c}\text { C18:1 } \\
(n-9)\end{array}$ & $\begin{array}{c}\mathrm{C} 18: 1 \\
(\mathrm{n}-7)\end{array}$ & $\begin{array}{c}\text { C18:2 } \\
(n-6)\end{array}$ & C18:3 & C20:0 & Total & saturated \\
\hline M. citrifolia juice & nd & 6.40 & 22.88 & 0.80 & 1.83 & 0.18 & 11.29 & 1.19 & 4.33 & 18.85 & 0.67 & 31.11 & 0.34 & 0.33 & 100 & 52.2 \\
\hline $\begin{array}{l}\text { Ripe fruits of } \\
\text { M. citrifolia }\end{array}$ & 0.71 & 19.24 & 58.0 & 1.54 & 0.16 & 0.14 & 0.49 & nd & nd & 0.06 & - & 0.05 & - & - & $\begin{array}{c}80.3 \\
9\end{array}$ & - \\
\hline Olive & nd & nd & nd & nd & nd & nd & 13.8 & 1. & 2.8 & 72 & - & 9.0 & 1.0 & nd & 100 & 83.4 \\
\hline Corn & nd & nd & nd & nd & nd & 0.0 & 11.7 & 0.1 & 2.2 & 31.6 & - & 53.0 & 0.8 & 0.4 & 100 & 85.5 \\
\hline
\end{tabular}

nd: not determined.

\subsection{Oil content and fatty acid composition of the oil extracted from the noni juice}

The three methods (Soxhlet, hexane juice and Folch) tested to extract oil and fatty acid from noni juice gave the same oil content of $(1.5 \pm 0.05) \mathrm{g} \cdot 100 \mathrm{~g}^{-1}$ dry matter for the Cambodian noni juice obtained by pressing. Comparison can be made with citrus fruit juices such as orange $\left(1.7 \mathrm{~g}\right.$ oil $\cdot 100 \mathrm{~g}^{-1}$ dry matter), tangerine $\left(1.8 \mathrm{~g}\right.$ oil $\cdot 100 \mathrm{~g}^{-1}$ dry matter) and grapefruit ( $1 \mathrm{~g}$ oil $\cdot 100 \mathrm{~g}^{-1}$ dry matter) [21]. The total content of unsaturated and polyunsaturated fatty acids of Cambodian Morinda citrifolia oil was $52.2 \mathrm{~g} \cdot 100 \mathrm{~g}^{-1}$ dry matter. This is, however, less than in corn $\left(85.5 \mathrm{~g} \cdot 100 \mathrm{~g}^{-1}\right.$ dry matter) or olive oils $\left(83.4 \mathrm{~g} \cdot 100 \mathrm{~g}^{-1}\right.$ dry matter). The study of fatty acid composition (table IX) shows the following elements:

- oil of Morinda citrifolia juice has a total composition in fatty acids similar to those of corn and olive oils,

- oleic acid C18:1 (n-9) is present in much greater quantity $\left(18.8 \mathrm{~g} \cdot 100 \mathrm{~g}^{-1}\right.$ oil) in noni oil than in the oil of the ripe fruits of Morinda citrifolia (0.06 $\mathrm{g} \cdot 100 \mathrm{~g}^{-1}$ oil) found by Farine et al. [28], which is astonishing and certainly due to a varietal variation. The amount of linoleic acid C18:2 (n-6) is lower $\left(31.1 \mathrm{~g} \cdot 100 \mathrm{~g}^{-1}\right.$ oil) than in corn oil (53 $\mathrm{g} \cdot 100 \mathrm{~g}^{-1}$ oil), but higher than in olive oil (9 $\mathrm{g} \cdot 100 \mathrm{~g}^{-1}$ oil). There was a low level of linolenic acid C18:3 (0.3 g.100 g $\mathrm{g}^{-1}$ oil) in the oil of noni juice.

One of the characteristics of this oil is that it contains a significant proportion of caprylic acid C8:0 (22.8 g·100 $\mathrm{g}^{-1}$ oil) and hexanoïc acid C6:0 (6.4 g·100 $\mathrm{g}^{-1}$ oil). The presence of these short-chain fatty acids could explain the unpleasant odor of Morinda citrifolia juice.

The iodine index of Cambodian noni juice oil was 72.3. This iodine index is rather low and is between that of palm oil (56.9) [29] and that of sunflower oil (90.0) [30] and olive oil (81.3) [31]. It is lower than that of unsaturated oils such as almond oil (100.3) [29] or corn oil (120.5) [32]. This is due to the high proportion of short-chain and saturated fatty acids shorter or equal to C12 (32 $\mathrm{g} \cdot 100 \mathrm{~g}^{-1}$ oil) contained in the oil, in spite of a good proportion of linoleic acid (31.1 $\mathrm{g} \cdot 100 \mathrm{~g}^{-1}$ oil).

\subsection{Summary chart of Morinda citrifolia juice composition}

The results obtained previously were brought together to give a summary of Morinda citrifolia juice composition (table $X$ ). 


\section{Table X.}

Summary chart of the composition of Morinda citrifolia fruit juice.

$\begin{array}{lcc}\text { Components } & \begin{array}{c}\text { Noni juice content } \\ \left(\mathrm{g} \cdot 100 \mathrm{~g}^{-1} \text { juice }\right)\end{array} & \begin{array}{c}\text { Noni juice content } \\ \left(\mathrm{g} \cdot 100 \mathrm{~g}^{-1} \text { dry matter in juice }\right)\end{array} \\ \mathrm{H}_{2} \mathrm{O} & 90.25 & 0 \\ \text { Proteins } & 2.5 & 25.6 \pm 0.3 \\ \text { Lipids } & 0.15 & 1.5 \pm 0.05 \\ \text { Mineral matter } & 0.86 & 8.8 \pm 0.3 \\ \text { Fibers } & 3.38 & 34.7 \pm 0.1 \\ \text { Total sugars } & 2.01 & 20.6 \pm 0.2 \\ \text { Mineral and organic anions } & 0.82 & 8.4 \pm 0.1 \\ \text { Chlorophyll } & 0.03 & 0.30 \pm 0.004 \\ \text { Total } & \cong 100 & \cong 100\end{array}$

\section{Conclusions}

Noni juice contains a low amount of oil (1.5 g.100 g ${ }^{-1}$ dry matter). This oil contains a high proportion of unsaturated fatty acids $\left(52.2 \mathrm{~g} \cdot 100 \mathrm{~g}^{-1}\right.$ oil) including $31.4 \mathrm{~g}$ polyunsaturated fatty acids $100 \mathrm{~g}^{-1}$ oil. Its main characteristic is that it contains a high proportion of short-chain fatty acids C6 to C10 which can play a considerable role in the unpleasant taste and odor of the juice, in particular when fatty acids are released by hydrolysis and become volatile during fruit maturation.

The significant quantity of simple sugars makes this juice a good energy-generating product for the human body. Simple sugars are mainly glucose $\left(12.2 \mathrm{~g} \cdot 100 \mathrm{~g}^{-1}\right.$ dry matter) and fructose $\left(8.4 \mathrm{~g} \cdot 100 \mathrm{~g}^{-1}\right.$ dry matter). The juice contains only traces of sucrose (<0.03 g. $100 \mathrm{~g}^{-1}$ dry matter).

Inorganic and organic anions which are found in large quantity $\left(8.4 \mathrm{~g} \cdot 100 \mathrm{~g}^{-1}\right.$ dry matter) could also be responsible for the characteristic taste of this juice.

The mineral content of the juice is also significant ( $8.8 \mathrm{~g} \cdot 100 \mathrm{~g}^{-1}$ dry matter). All the important minerals for the body are found in the juice and fibres of noni: $\mathrm{P}, \mathrm{K}, \mathrm{Ca}, \mathrm{Mg}$, $\mathrm{Na}, \mathrm{S}$ and Se.

Noni juice contains an average of $25.6 \mathrm{~g}$ protein $100 \mathrm{~g}^{-1}$ dry matter. This quantity depends on the source of the fruit and the manufacturing method of the juice.
Complementary studies were done to ensure physical and microbiological stabilization of noni juice [33] for its marketing. The juice was clarified by tangential microfiltration and was concentrated by reverse osmosis. The juice obtained is much clearer and less turbid than the industrial Tahitian juice. Pasteurization at $70{ }^{\circ} \mathrm{C}$ for $10 \mathrm{~min}$ associated with these two techniques and the relatively low $\mathrm{pH}$ of the juice (3.7) permitted us to obtain a juice which was stable over 7 months.

Noni juice thus could find some applications in:

- the pharmaceutical or dietetic industries, but the juice must preserve its traditional properties after stabilization;

- the animal feed industry for the residual cake and the seed oil, whose compositions are quite close to the cakes or seeds usually used in this sector [33].

In spite of many new analyses carried out on noni juice and its derivatives, the juice of Morinda citrifolia fruit will keep its health-giving and curing secrets. The analyses showed that this product contains molecules with undeniable antioxidant properties which could have an action on the human body. Many texts resulting from local populations as well as the significance of the production of this juice in tropical countries make us think that noni juice contains additional active molecules at a medicinal level such as certain alkaloids like xeronine, often quoted by certain business corporations, but which have never been isolated, or identified.

\section{References}

[1] Chopra R.N., Nayar S.L., Chopra I.C., Glossary of Indian medicinal plants, Council of Scientific and Industrial Research, New Delhi, India, 1956, 330 p.

[2] Adjanohoun E.J., Aké Assi L., Eyme J., Gassita J.N., Goudote E., Gueho J., Lackaria F.S.L., Ip D., Kalachand S.K.K., Keita A., Koudogbo, Land-Reau D., Owadally A.W., Soopramanien A., Contribution aux études ethnobotaniques et floristiques à Maurice (îles Maurice et Rodrigues), Agence de Coopération Culturelle et Technique, Paris, France, 1983, $214 \mathrm{p}$. 
[3] Singh Y.N., Ikahihif T., Paune M., Slatter C., Folk medicine in Tonga. A study on the use of herbal medicines for obstetric and gynaecological conditions and disorders, J. Ethnopharmacol. 12 (1984) 305-329.

[4] Singh Y.N., Traditional medicine in Fiji: some herbal folk cures used by Fiji Indians, J. Ethnopharmacol. 15 (1986) 57-88.

[5] Dixon A.R., McMillen H., Etkin N.L., The transformation of noni, a traditional Polynesian medicine (Morinda citrifolia, Rubiaceae), Econ. Bot. 53 (1999) 51-68.

[6] Wang M.Y., Su C., Cancer preventive effect of Morinda citrifolia (noni), Ann. NY Acad. Sci. 952 (2001) 161-162.

[7] Morton J.F., The ocean-going noni, or Indian mulberry (Morinda citrifolia, Rubiaceae) and some of its "colorful" relatives, Econ. Bot. 46 (1992) 241-256.

[8] Solomon N., Noni phenomenon: discover the powerful tropical healer that fights cancer, lowers high blood pressure and relieves chronic pain, in: Direct source publishing, South Orem, USA, 1999.

[9] Anonymous, Solids (total) and moisture in flour. Air oven method, in: Official methods of analysis of the Association of Official Analytical Chemists (AOAC), Vol. 2, 15th ed., USA, 1990, $777 \mathrm{p}$.

[10] Anonymous, Ash of flour. Direct method, in: Official methods of analysis of the Association of Official Analytical Chemists (AOAC), Vol. 2, 15th ed., USA, 1990, 777 p.

[11] Anonymous, Procédure opérationnelle. Dosages de $\mathrm{P}, \mathrm{K}, \mathrm{Ca}, \mathrm{Mg}, \mathrm{Fe}, \mathrm{Mn}, \mathrm{Zn}$ et Se par spectrométrie d'émission plasma I.C.P., in: Analyse de végétaux, Code : I.L. ICP., CiradAmis/Agronomie, 2002, p. 3.

[12] Anonymous, Procédure opérationnelle. Détermination de la teneur en azote total, in: Analyse de végétaux, Code : NPS0931, CiradAmis/Agronomie, 2002, p. 4.

[13] Anonymous, Procédure opérationnelle. Détermination de la teneur en matière grasse, Code : PC0918A, Cirad-Amis/Paa, 2002, pp. 1-5.

[14] Folch J., Lees M., Sloane G.S.H., A simple method for the isolation and purification of total lipids from animal tissue, J. Biol. Chem. 226 (1957) 497-509.

[15] Anonymous, Procédure opérationnelle. Préparation des esters méthyliques. Code : PC 019D, Cirad-Amis/Paa, 2002, pp. 1-6.
[16] Anonymous, Procédure opérationnelle. Extraction des sucres au reflux d'éthanol à $80 \%$, Code : PC 0901A, Cirad-Amis/Paa, 1999, pp. 1-6.

[17] Anonymous, Procédure opérationnelle. Dosage des mono et disaccharides par chromatographie ionique DX600, Code : PC 08A, CiradAmis/Paa, 2001, pp. 1-7.

[18] Anonymous, Procédure opérationnelle. Détermination de la cellulose brute, Code: PC 0930B, Cirad-Amis/Paa, 2001, pp. 1-7.

[19] Arnon D.I., Copper enzymes in isolated chlorophlasts and polyphenol oxidase in Beta vulgaris, Plant Physiol. 24 (1949) 1-15.

[20] Anonymous, Procédure opérationnelle. Dosage des anions organiques par chromatographie ionique, Code : PC 0911B, Cirad-Amis/Paa, 2001, pp. 1-7.

[21] Rakipov N., Biochimie des cultures tropicales, Moscou, Russie, 1987.

[22] Minguez-Mosquera M.I., Gandul-Rojas B., Gallardo-Guerrero M.L., Rapid method of quantification of chlorophylls and carotenoids in virgin olive oil by High-Performance Liquid Chromatography, J. Am. Oil Chem. Soc. 40 (1992) 60-63.

[23] Wauchope R.D., Selenium and arsenic levels in soybeans from different production regions of the United States, J. Agric. Food Chem. 26 (1978) 226-228.

[24] Wijesundera R.C., Ackman R.G., Abraham V., de Man J.M., Determination of sulfur contents of vegetable and marine oils by ion chromatography and indirect ultraviolet photometry of their combustion products, J. Am. Oil Chem. Soc. 65 (1988) 1526-1530.

[25] Alais C., Linden G., Biochimie alimentaire, Masson, Paris, France, 1994.

[26] Morr C.V., Recalculated nitrogen conversion factors for several soybean protein products, J. Food Sci. 47 (1982) 1751-1752.

[27] Hulse J.H., Rachie K.O., Billingsley L.W., Nutritional standards and methods of evaluation for food legume breeders, IDRC, Ottawa, Canada, 1977.

[28] Farine J.P., Legal L., Moreteau B., Le Quere J.L., Volatile components of ripe fruits of Morinda citrifolia and their effects on Drosophila, Photochem. 41 (1996) 433-438.

[29] Itoh T., Tamura T., Matsumoto T., Sterols and methylsterols in some tropical and subtropical vegetable oils, Oléagineux 5 (1974) 253258. 
[30] Pérez-Galvez A., Garrido-Fernandez J., Minguez-Mosquera I.M., Effect of high-oleic sunflower seed on the carotenoid stability of ground pepper, J. Am. Oil Chem. Soc. 77 (2000) 79-83.

[31] Kamal-Eldin A., Andersson R.A., Multivariate study of the correlation between tocopherol content and fatty acid composition in vegetable oils, J. Am. Oil Chem. Soc. 74 (1997) 375-380.
[32] Gordon M.H., Miller L.A.D., Development of steryl ester analysis for the detection of admixtures of vegetable oils, J. Am. Oil Chem. Soc. 74 (1997) 505-510.

[33] Chunhieng T., Développement de nouveaux aliments santé à partir de graines et fruits d'origine tropicale : application à la noix du Brésil Bertholettia excelsa et au fruit du Cambodge Morinda citrifolia, INPL, Thèse, Nancy, France, 2003.

\section{Estudio detallado de la composición del jugo de noni (Morinda citrifolia) cultivado en Camboya.}

Resumen - Introducción. El noni (Morinda citrifolia) tiene una larga historia vinculada a su uso medicinal en los países del sudeste asiático. Hoy día, la planta crece en la mayoría de las regiones del Pacífico Sur, en la India, el Caribe, América del Sur y las Antillas. Uno de los retos de estos últimos años fue intentar extraer el jugo del fruto de $M$. citrifolia para emplear en la farmacopea moderna este producto tradicional. Para comprender mejor las características medicinales del fruto de noni cultivado en Camboya, se determinó la composición bioquímica y mineral del jugo bruto extraído de frutos de $M$. citrifolia. Material y métodos. Se transportaron a Francia frutos frescos enteros de $M$. Citrifolia, muestreados en Camboya, y se conservaron a $-20{ }^{\circ} \mathrm{C}$ durante toda la duración del experimento. Se compró jugo comercial de noni de Tahití para utilizarlo como referencia. Se efectuó una extracción en dos series de frutos de Camboya utilizando una prensa hidráulica. Se analizaron las tasas de aceite, ácidos grasos, proteínas, aminoácidos, azúcares y elementos minerales de los jugos. Resultados. La composición del jugo de nonis de diferentes orígenes se determinó, comparó y examinó con relación a la composición bioquímica y mineral de otros aceites vegetales. Conclusión. La composición bioquímica de jugo, que mostró una alta presencia de moléculas antioxidantes, no basta para explicar los conocidos efectos medicinales del jugo de Noni. Aún quedan por estudiar algunas moléculas, especialmente los alcaloides.

Camboya / Morinda citrifolia / fruto / composición aproximada / aceites / proteínas / contenido mineral 